\title{
Green Design and Planning Resolutions for an Eco-Industrial Town: A Case Study of Polluted Industrial Estate in Rayong Province, Thailand
}

\section{Ariya Aruninta}

Department of Landscape Architecture, Faculty of Architecture, Chulalongkorn University, Bangkok, Thailand.

Email: aariya@chula.ac.th

Received August $9^{\text {th }}, 2012$; revised September $7^{\text {th }}, 2012$; accepted October $5^{\text {th }}, 2012$

\begin{abstract}
Map Ta Phut was designated for development in national policy as an Eastern Seaboard Industrial Port. It is located in Rayong Province with growing demand from Eastern Seaboard industries and is heavily affected by serious environmental problems as a "pollution control zone". While the Joint Standing Committee on Commerce, Industry and Banking, representing the national business sector, claimed that the area generated total revenues of 1.1 trillion baht per year, or $11 \%$ of Thailand's gross domestic product, and employed more than 100,000 workers, the declaration of the area as a pollution control zone severely limited investment and business operations. Thus, controversies arose among the investment business sectors, the residential sector (residents have been affected by a decrease in their quality of life and health) and environmental concern sectors. This paper aims to find an efficient and practical mitigation practice to balance the purposes of the industrial port with protection of surrounding communities and natural resources. The author will apply physical design and planning such as the application of "buffer zones”, "greenbelts", "set-back", "green corridor", "green wall" and "protection strips" along with environmental measurements such as the Air Pollution Tolerance Index (APTI), which can be adapted for pollution protection as best practices of landscape architecture.
\end{abstract}

Keywords: Air Quality; Eco-Industrial Town; Buffer; Pollution Protection; Landscape Indicator

\section{Introduction}

The Eastern Seaboard Industrial Port is located mainly in Rayong Province, only approximately $120 \mathrm{~km}$ east of Bangkok. Rayong is a medium-sized province with an area of 3552 Sq. km. (2,220,000 Rais) and a population approximately 615,000. National policy has designated Map Ta Phut as the major industrial port under the Industrial Estate Authority of Thailand (IEAT). However, at the same time, the National Environment Board (NEB) declared the Map Ta Phut municipality and vicinity in three other sub-districts-heavily affected by serious environmental problems-as "pollution control zones" to control, reduce and eliminate toxic waste in accordance with guidelines contained in the National Environment Quality Act. The national policies support investment and regulate only extreme effects on the environment, requiring Environmental Impact Assessment (EIA) and Health Impact Assessment (HIA) reports to be attached with the project proposal.

Land development in Thailand is regulated by the Land-Use Master Plan from the Department of Public Works, Town \& Country Planning, and development proposals have to be granted building permission by responsible agencies. Currently, there is no comprehensive master plan besides the colored land-use plan to control development. For industrial estates such as Map Ta Phut, land-use plans have been developed according to demand and actual development. Between the years 1988, 1991, and 2003, there were significant changes to the use of the area, shifting from agriculture (green) to industrial (purple), and the existing residential area (yellow) became gentrified, changing from agriculture-based to Industry-based communities. In addition, one of the communities was replaced with an industrial estate and relocated.

The plans for future expansions of this area have been developed with a cost of more than one billion Thai baht, including land reclamation. These plans would lead to a more severe impact to the environment, especially affecting communities around the heavily industrial area. The national business sector supports this development because the area generated total revenues of $\mathrm{Bt} 1.1$ trillion baht a year, or $11 \%$ of Thailand's gross domestic product, and employed more than 100,000 workers. Declaring the area a pollution control zone severely limits 

in Rayong Province, Thailand
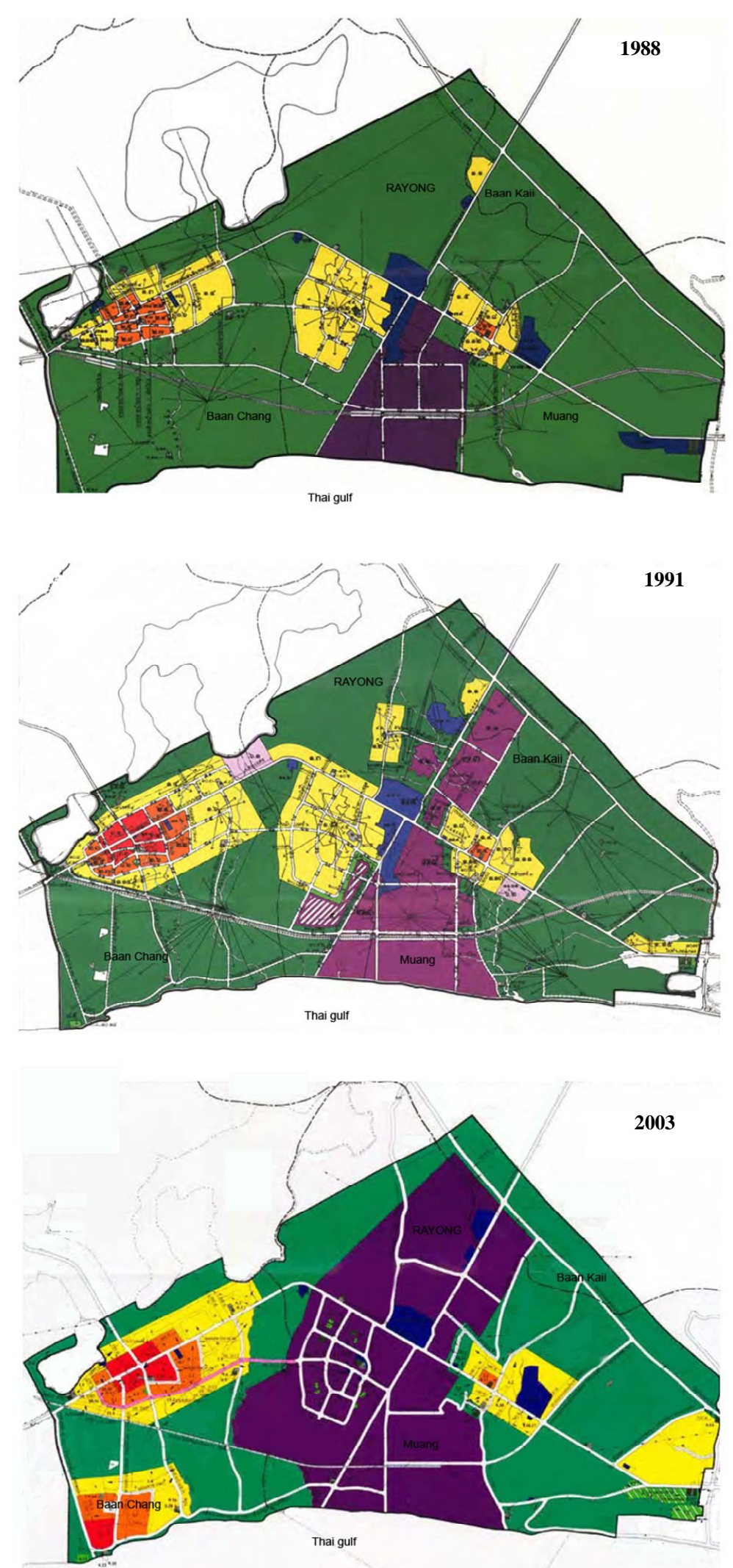

Figure 1. Land-use master plans of the map Ta Phut area show land-use changes. (Source: Department of Public Works, Town \& Country Planning). 
investment and business operations. Other areas along the seashore seem to have the same problem as Map Ta Phut (Figure 2). The IEAT also introduced a five-year plan (2007-2011) to mitigate the pollution problem in Rayong with a cost of 21,089 million baht. The plan includes 217 project proposals and decentralizes the environmental plan, especially in shifting mitigation from the central to local government.

According to the Rayong Provincial Office of the Ministry of Industry, there are four types of industrial zone: industrial estates, industrial business zones, industrial communities and industrial parks. The total area of all types of industrial zones covered only $1.8 \%$ of the entire Rayong province. Moreover, besides the factories in the industrial zones, there are several factories all over the province. Data from the Rayong Provincial Office of the Ministry of Industry (2007) showed that there were 1704 factories in Rayong, and 1374 of those factories are outside the industrial zones with only 330 factories (less than $20 \%$ ) located in the restricted industrial zones. These data suggest that more than $80 \%$ of factories in Rayong Province are independently established and have been contributing to pollution problems without properly management by the responsible agencies.

The author concluded in a previous study on land planning that many cities showed uncontrolled sprawl, which is associated with many urban problems such as transportation problems, unsafe places, improper land use, poor city atmosphere and visual pollution [1]. The case of industrial estates is another example of uncon- trolled sprawl similar to other land development in Thailand. Theoretically, the industrial zones should be buff ered when they are located next to residential zones or environmentally sensitive zones, and ideally, they should be as far away as possible from residential zones when it is applicable.

\section{Ecology vs Industry}

The National Petrochemical Development Plan aims to make Map Ta Phut a more ecologically responsible industrial estate with the theme "Clean \& green port with faster and better services". Questions have been raised about how ecology can get along with industry. Planning of the Map Ta Phut Industrial Estate at different stages still have not clearly shown ecological approaches in its concepts along with an economic approach. The layout plan of every other industrial estate and each individual factory seemed to be designed solely by the criteria of functional logistics and financial feasibility. Each plot has its own planners without integration of the overall plan for the area. The "Clean \& green port with faster and better services" concept can be seen in the planning only for "the faster and better services" because most of the factories were located on the seashore by the port and easily accessed by major roads; the presence of the "Clean” and "Green” concepts are doubted.

\section{Problems and Impacts}

In last decade, in the third phase of the National Petro-

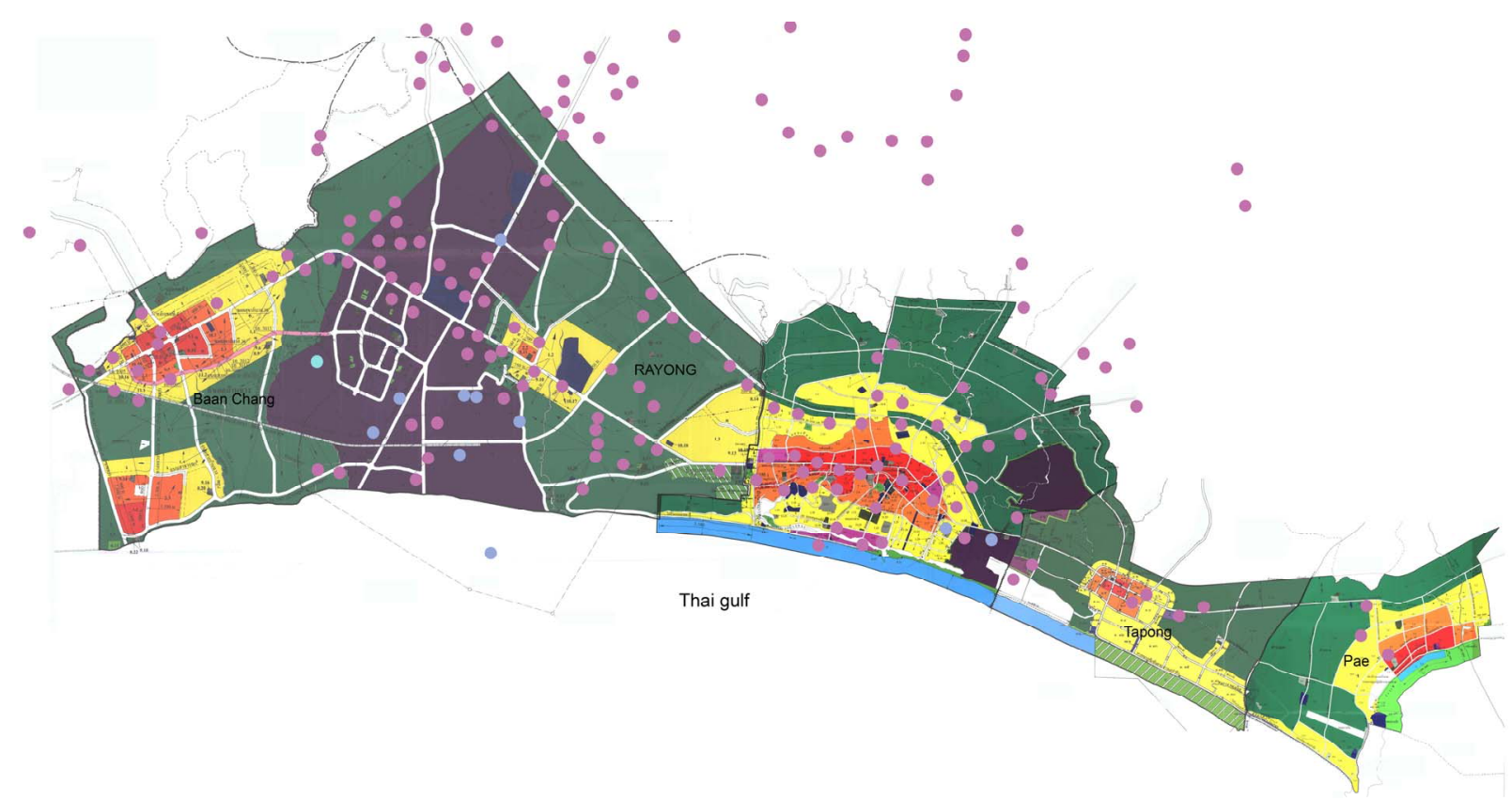

Figure 2. Overlay map of pollution spots and land-use master plans of seashore area (Excerpted by A. Aruninta. Sources: Department of Public Works, Town \& Country Planning, Rayong Provincial Office, Ministry of Industry). 
chemical Development Plan, the number of petrochemical industry projects were increased significantly, and the provincial land-use master plan was shifted from developing green and residential zones to expanding the industrial zone. Although the plan's objectives target is the "Clean \& Green Port with the faster and better services," the area was designated a pollution control zone by the NEB due to inefficient hazardous waste management systems and the toxic chemicals released into the environment by factories in the industrial estate. There have been controversies among the business investment, environmental concern, and residential sectors, with residents affected by a decline in quality of life and health. Thus, the government introduced several measures for pollution reduction, such as mandating that new investment comply with the 80:20 emission reduction and reservetion scheme, and installing emission monitoring and warning systems in the most condensed and sensitive areas.

The environmental Non-Governmental Organization (NGO), "Stop Global Warming Association”, submitted a petition to the administrative court to suspend project proposals that do not follow Article 67, Clause 2, of the new Constitution of the Kingdom of Thailand BE 2550 (2007), which states that any activities which may cause a highly significant impact on the environment and create risk for the health of people in the community must pass a process of environmental and health impact assessment as well as a public hearing, including comments by an independent organization. To be accountable to foreign investors and the public, the Thai cabinet appointed a four-party panel, consisting of members from public agencies, the private sector, academia and NGOs to resolve the problem. The suggestions from the panel were used in establishing rules and regulations for the involved organizations, i.e., the NEB, the Ministry of Industry and the proposed independent organization. The eight industry types which potentially generate highly significant impact were defined by the Ministry of Industry, and these types are required to have HIA/EIA reports as well as public hearings. The list was used by the Supreme Administrative Court to release the temporary suspension order of 76 projects due to the complaint from the national level NGO.

In the Rayong Industrial Estate area, there are mainly clusters of the upstream or intermediate petrochemical industry (using or manufacturing hazardous air pollutants), power plants, and also some steel industries. Therefore, the author reviewed the impact of these types of manufacturers on the environment and assessed the implementation of pollution reduction measures to determine whether they offer sufficient and satisfactory control, especially as determined from the present ambi- ent air quality near the factories. Some literature on environmental engineering indicated that iron and steel factories are a significant point source for air pollutants such as $\mathrm{SO}_{2}, \mathrm{CO}_{2}, \mathrm{NO}_{2}$ and heavy metals [2]. The most important toxic waste from the petrochemical industry are Volatile Organic Compounds (VOCs), which are organic chemical compounds that have high enough vapor pressures under normal conditions to vaporize significantly and enter the air. VOCs are noted by the International Agency for Research on Cancer (IARC) and the World Health Organization (WHO) as a cause of human cancer. The accumulated data from the pollution emission monitoring stations in Map Ta Phut and IRPC near the Muang District for 2011 (see Figure 3) found the following VOCs over satisfactory levels: 1,3-Butadiene, Benzene and 1,2-Dichloroethane (IRPC stations showed a satisfactory level for the last VOC). However, Vinyl Chloride, Chloroform, Dichloromethane, Trichloro-ethylene, 1,2-Dichloropropane and Tetrachloroethylene were all at satisfactory levels.

\section{The Applications of Green Design and Planning}

Landscape architecture becomes an important consideration as an efficient and practical mitigation practice for balancing the purposes of the industrial port with the protection of surrounding communities and natural resources. The application of landscape architecture and plantings may offer an accessorial option [2] and serve aesthetic aims. The author has argued for applying landscape architectural science using different tools such as landscape indicators like the Air Pollution Tolerance Index (APTI) in the design and planting of a green belt. Vegetation is recognized as a filter that naturally cleanses the atmosphere by absorbing gases and some particulate matter through its leaves, efficiently trapping some pollutants [3] and also removing atmospheric $\mathrm{CO}_{2}$ by storing it as woody biomass [4]. Another important characteristic is tolerance in plants: tolerant, intermediate, sensitive, and very sensitive plants can be adapted for pollution protection and as "bio-indicators" in the best practices of landscape architecture.

Bio-indicators: "Ecotoxicological studies" and other new fields in the environmental sciences have studied the effects of air pollutants on plants and the use of plants for monitoring air quality [5]. For example, lichens can be used as air quality "bio-indicators" based on their sensitivity to gaseous pollutants, especially $\mathrm{SO}_{2}$, fluorides and strongly oxidizing compounds such as ozone. The physical, chemical and biological properties of lichens are also used as monitors of metal deposition from the atmosphere [6]. Therefore, lichens can integrate air pollu- 

in Rayong Province, Thailand
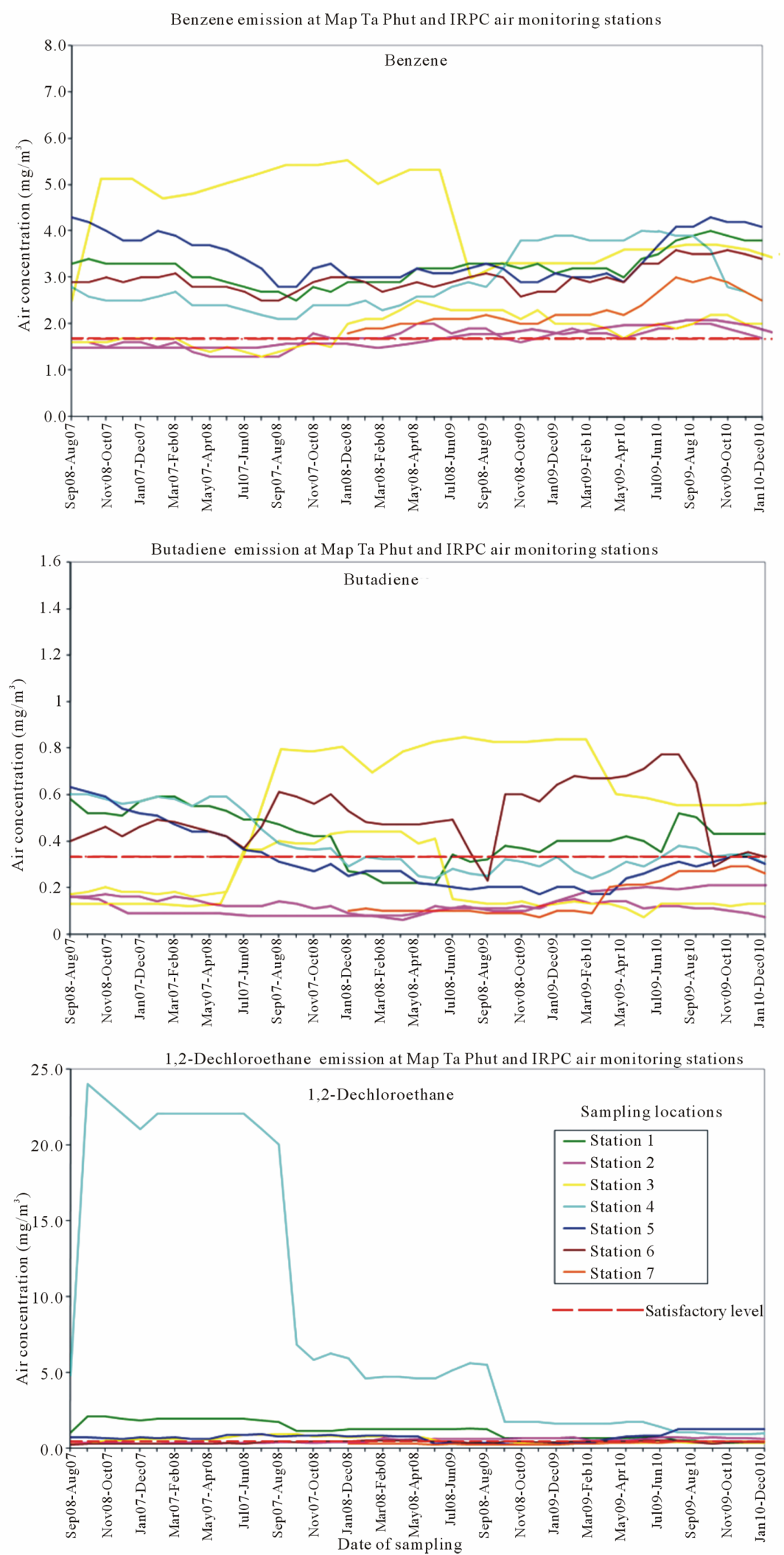

Figure 3. Charts show high levels above a satisfactory level (red dash line) of these accumulated VOCs; Benzene, Butadiene, and 1,2-Dichloroethane; in the Map Ta Phut and IRPC area (Excerpted by A. Aruninta. Sources: Pollution Control Department 2011). 
tion monitoring and other indicators called the plant factors, which are often used as early indicators of air pollution stress [5]. We assume that air pollutants can affect plants directly via leaves and indirectly via soil acidification [7]; thus, we have used physiological changes to estimate the plant's tolerance.

In summary, the APTI has gradations for different levels of tolerance, and the spectrum is usually divided into four grades: 1) Tolerant or higher index values, 2) Moderate, 3) Intermediate, and 4) Sensitive or lower index values [2,3,8]. Singh et al. (1991) also stressed that the identification and categorization of plants into sensitive and tolerant groups is important because the former can serve as indicators and the latter as sinks for the abatement of air pollution in urban and industrial habitats. The more tolerant plants can be used for buffering purposes and the more sensitive plants can be used as bio-indicators. Herbs, shrubs and trees have been ranked differently in their sensitivity to air pollutants: herbs $>$ shrubs $>$ trees [3]. Thus, APTIs of most shrubs were higher or more tolerant to air pollution than those of trees. We can use shrubs as part of the "green wall" in the area where set-back distance is not applicable (Figure 4), and they can be mixed with other tolerant trees in layers to provide all levels of absorbers where space available.

Buffering and cushioning: In the context of environmental engineering, greenbelts have been widely used to reduce or cushion the impact of and severe damage from explosions, fires and toxic release from factories. "Greenbelts" are man-made strips of vegetation-predominantly trees with shrubs interspersed-which are designed and located around industries and other sources of air pollutants. They are not substitutes for air pollution control measures, however, but greenbelts can also play the role of beautifying the area [9]. The benefits are categorized as intangible benefits (e.g., scenic quality, recreation and relaxation opportunities and wildlife habitat) and cost

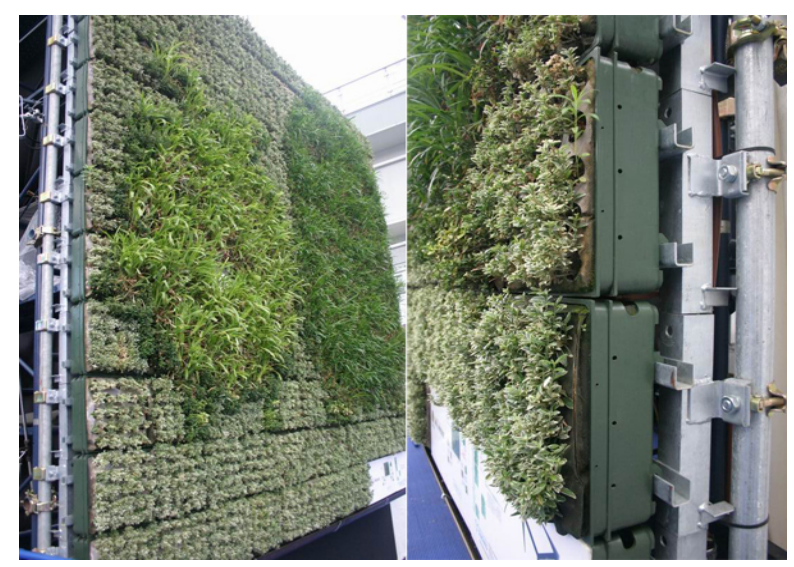

Figure 4. Example of a greenwall using a variety of plants (A. Aruninta). benefits (e.g., energy savings, uptake of $\mathrm{CO}_{2}$ and other air pollutants and integrated air quality improvement measure) [4]. The effectiveness of a greenbelt in intercepting and retaining atmospheric pollutants depends on several factors such as shape, size, moisture level and surface texture as well as which air pollutants may be adsorbed, absorbed, accumulated, detoxificated, metabolized or integrated into the plant body. Greenbelts have the ability to leave the air relatively free of pollutants and also improve air quality by providing oxygen to atmosphere [3].

The ability of greenbelt plants to trap pollution is related to large leaf size and dense foliage or a thick canopy. For retention of pollutants, multiple rows across the direction of the wind is also recommended for better absorption [9]. Shannigraphi, Fukushima, and Sharma also concluded that out of 30 species, Mangifera indica (the mango tree) was the most tolerant plant and performed well as the first curtain plant of a greenbelt, with other excellent performers including Ficus benghalensis, Ficus infectoria and Mimusops elengi.

Another aspect of green buffer design is that trees can suffer from chronic toxicity symptoms due to the continuing impact of low level pollution [10], so the maintenance and monitoring of the greenbelt areas is needed. It is important to have service lanes for access to all areas and to perform frequent observations of growth rate, plant pathogens and syndromes. These observations should be recorded, and replacement and re-planting of the greenbelts may be needed.

Other benefits of the better eco-industrial town: Identified from mapping studies, there are factories situated outside the industrial zone along the main streets; therefore, a "green corridor" can be applied to these main streets. Together with a city's "green lung," it is the place where parks and urban forests exist (Figure 5). It is com monly recognized by the public now, and the green area in a city should be a basic requirement in all planning. McPherson, Scott, and Simpson [4] explained that trees absorb gaseous pollutants through leaf stomata and can bind or dissolve water soluble pollutants on moist leaf surfaces. Tree canopies also intercept particulates and reduce local air temperatures, and micro climates are the most effective energy efficiency programs [11]. Therefore, planning a "green system" in industrial areas is not just an accessorial option, and it should be combined with the transportation system, utilities and piping systems, water system and other management and logistical systems. Sustainable development of the eco-industrial town should consider the land utilization "tripod" [12] and focus more on the reinvention of public green space to encourage land use for other purposes than only traditional economic benefit. 


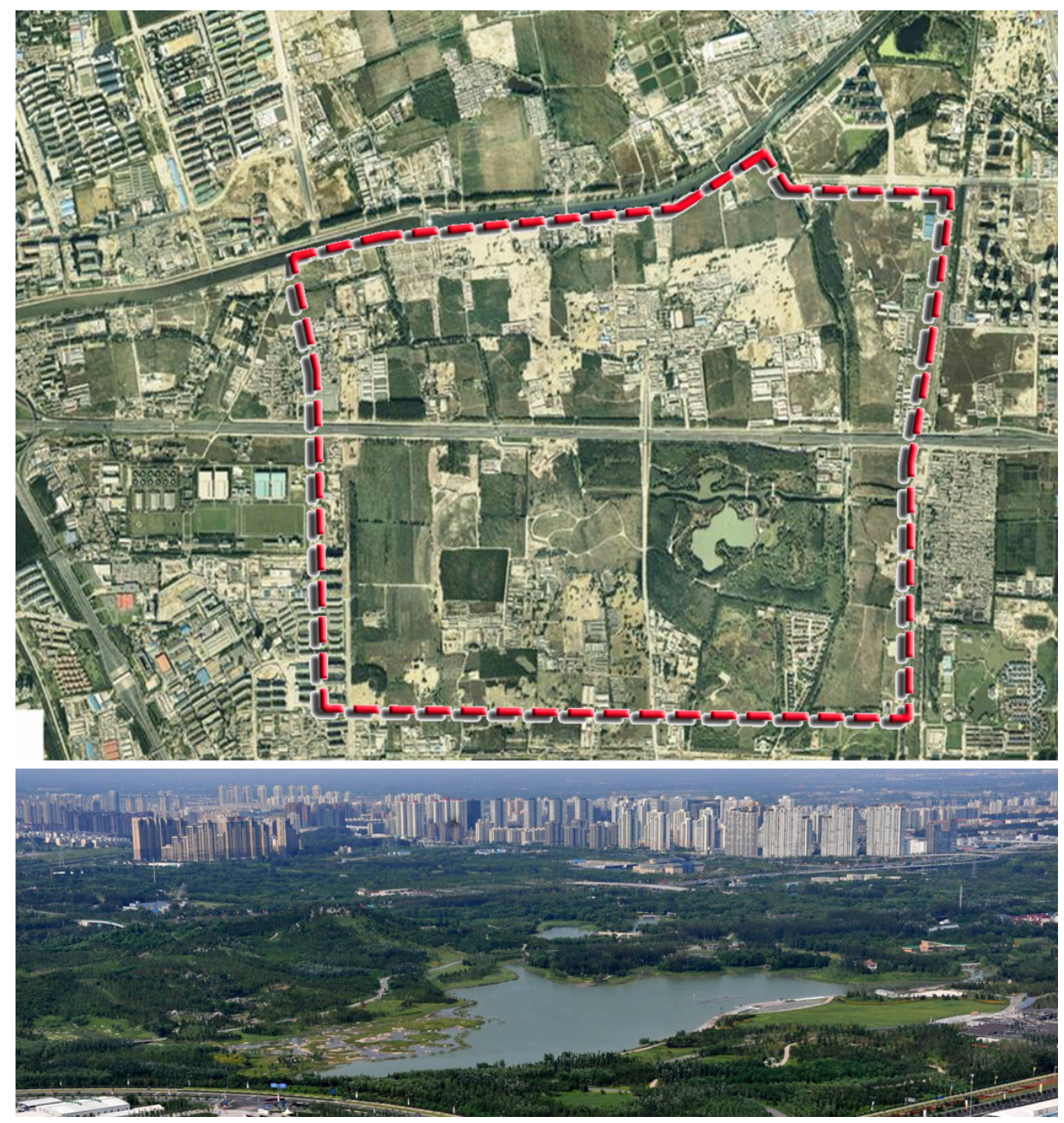

Figure 5. The 2008 Olympic Forest Park was originally planned to be “a green lung” of Beijing (Sources: Beijing Tsinghua Urban Planning \& Design Institute).

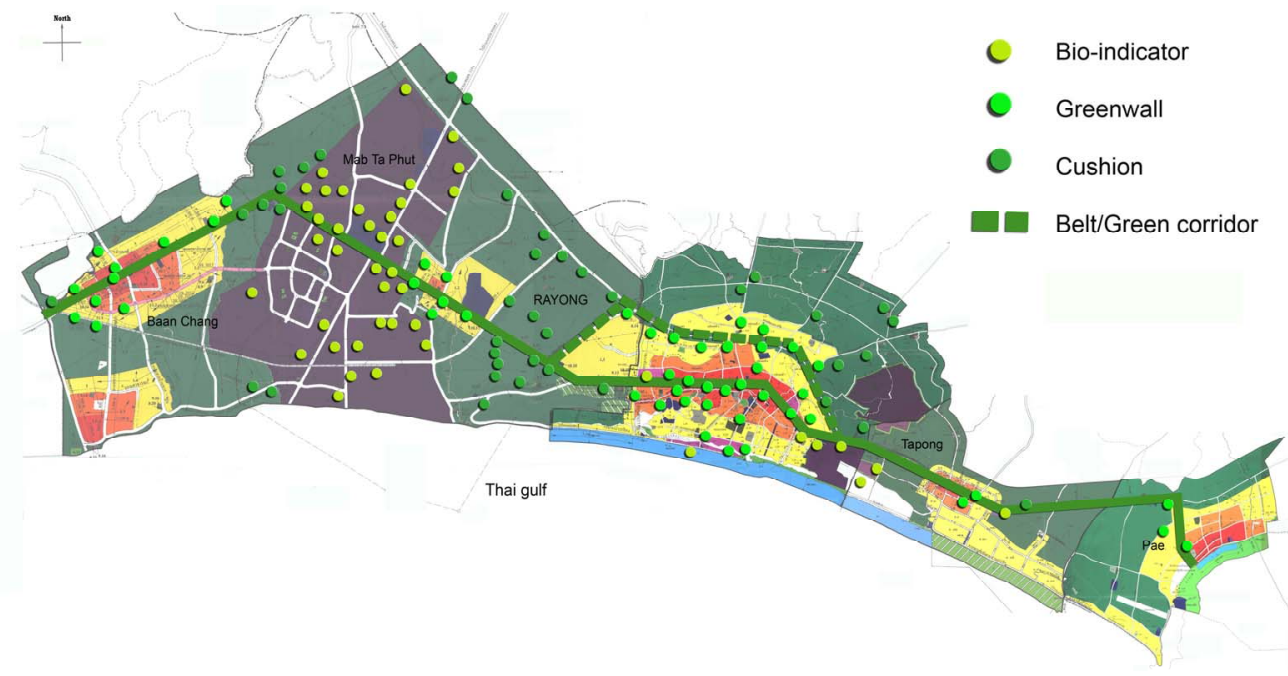

Figure 6. Overlay map of the proposed 1) Bio-indicator, 2) Greenwall, 3) Cushion, and 4) Green corridor as “a green area system” on the Land-Use Master Plan for the seashore area (Excerpted by A. Aruninta. Sources: Department of Public Works and Town \& Country Planning). 
Sustainable development should also emphasize socioeconomic factors. The election of plant species in a greenbelt is not only determined and evaluated by biological and biochemical characteristics, such as APTI, plant habit, canopy structure, type of plant and laminar structure [3], but also socioeconomic values such as maintenance cost and community preferences. Plants with longer lifespan are also preferred for economic returns.

\section{Conclusion}

Combining all factors and purposes, landscape architectural science and the art of designing green buffers for eco-industrial towns such as the Rayong Industrial Estates are crucial and effective measures. Landscape design, especially planting design, offers wide benefits including aesthetic, socioeconomic and ecological (such as bio-indicator, biochemical filtering of the air and reduction of temperature). Designing a green buffer-i.e., "green corridor", "green lung”, "green wall”, "cushion" and "bio-indicator"-requires an understanding of environmental engineering science, horticulture, micro climates and meteorological conditions and the release pattern and chemical dispersion behavior of the pollutants. Finally, the study suggests having a "green area system" (Figure 6), which is a significant consideration of green planning together with other systems. Providing an efficient green area system would involve pollutant attenuators, absorbers, trappers, indicators, cushions and buffers that do the utmost to promote sustainable planning and prevent industrial disaster for the eco-industrial town.

\section{Acknowledgements}

This paper was presented and published in the proceeding of the ICHES2011: The 4th International Conference on Human-Environment System, 3-6 October, 2011. Hosted by Japanese Society of Human-Environment System, Hokkaido University.

\section{REFERENCES}

[1] A. Aruninta, "Public Land Management Policy for Urban Vacant Land: The Development of a Public Land Management Policy for Under-utilized Space in Bangkok, Thailand,” VDM Verlag Dr. Muller, Germany, 2010.

[2] J. Liu and H. Ding, "Variation in Air Pollution Tolerance
Index of Plants near a Steel Factory: Implications for Landscape-Plant Species Selection for Industrial Areas," WSEAS Transactions on Environment and Development, Vol. 4, No. 1, 2008, pp. 24-32.

[3] A. S. Shannigrahia, T. Fukushimaa and R. C. Sharmab, "Anticipated Air Pollution Tolerance of Some Plant Species Considered for Green Belt Development in and around an Industrial/Urban Area in India: An Overview," International Journal of Environmental Studies, Vol. 61, No. 2, 2004, pp. 125-137. doi:10.1080/0020723032000163137

[4] E. G. McPherson, K. I. Scott and J. R. Simpson, "Estimating Cost Effectiveness of Residential Yard Trees for Improving Air Quality in Sacramento, California, Using Existing Models,” Atmospheric Environment, Vol. 32, No. 1, 1998, pp. 75-84.

[5] G. Klumpp, et al., "Response of Stress Indicators and Growth Parameters of Tibouchina Pulchra Cogn. Exposed to Air and Soil Pollution near the Industrial Complex of Cubatao, Brazil,” The Science of the Total Environment, Vol. 246, 2000, pp. 79-91.

[6] Z. Jeran, et al., "Lichens as Integrating Air Pollution Monitors,” Environmental Pollution, Vol. 120, 2002, pp. 107-113.

[7] L. Steubing, et al., "Effects of $\mathrm{SO}_{2}, \mathrm{NO}_{2}$, and $\mathrm{O}_{3}$ on Population Development and Morphological and Physiological Parameters of Native Herb Layer Species in a Beech Forest,” Environmental Pollution, Vol. 58, 1989, pp. 281-302. doi:10.1016/0269-7491(89)90140-1

[8] S. K. Singh, et al., "Air Pollution Tolerance Index of Plants,” Journal of Environmental Management, Vol. 32, 1991, pp. 45-55. doi:10.1016/S0301-4797(05)80080-5

[9] F. I. Khan and S. A. Abbasi, "Cushioning the Impact of Toxic Release from Runaway Industrial Accidents with Greenbelts," Journal of Loss Prevention in the Process Industries, Vol. 13, 2000, pp. 109-124. doi:10.1016/S0950-4230(99)00069-8

[10] A. P. Turner, N. M. Dickinson and N. W. Lepp, "Indices of Metal Tolerance in Trees," Water, Air, and Soil Pollution, Vol. 57-58, 1991, pp. 617-625. doi:10.1007/BF00282925

[11] M. Weedall, "What We Know about Shade Trees and Energy Use in Sacramento. In Benefits of the Urban Forest, Sacramento, CA,” Sacramento Municipal Utility District, 1995, pp. 5-6.

[12] A. Aruninta, “WiMBY: A Comparative Interests Analysis of the Heterogeneity of Redevelopment of Publicly Owned Vacant Land,” Landscape and Urban Planning, Vol. 93, 2009, pp. 38-45. doi:10.1016/j.landurbplan.2009.06.005 